\title{
On Optimal Production and the Market to Book Ratio Given Limited Shareholder Diversification
}

\author{
Thomas Conine \\ Fairfield University, tconine@fairfield.edu \\ Oscar W. Jensen \\ Fairfield University \\ Maurry Tamarkin \\ Clark University
}

Follow this and additional works at: https://digitalcommons.fairfield.edu/business-facultypubs

\section{Peer Reviewed}

\section{Repository Citation}

Conine, Thomas; Jensen, Oscar W.; and Tamarkin, Maurry, "On Optimal Production and the Market to Book Ratio Given Limited Shareholder Diversification" (1989). Business Faculty Publications. 3.

https://digitalcommons.fairfield.edu/business-facultypubs/3

\section{Published Citation}

Conine, Thomas, Oscar W. Jensen, and Maurry Tamarkin. "On Optimal Production and the Market to Book Ratio Given Limited Shareholder Diversification." Management Science 35.8 (Aug 1989): 1004-1013.

This item has been accepted for inclusion in DigitalCommons@Fairfield by an authorized administrator of DigitalCommons@Fairfield. It is brought to you by DigitalCommons@Fairfield with permission from the rightsholder(s) and is protected by copyright and/or related rights. You are free to use this item in any way that is permitted by the copyright and related rights legislation that applies to your use. For other uses, you need to obtain permission from the rights-holder(s) directly, unless additional rights are indicated by a Creative Commons license in the record and/or on the work itself. For more information, please contact digitalcommons@fairfield.edu. 


\title{
ON OPTIMAL PRODUCTION AND THE MARKET TO BOOK RATIO GIVEN LIMITED SHAREHOLDER DIVERSIFICATION*
}

\author{
THOMAS E. CONINE, JR., OSCAR W. JENSEN AND MAURRY TAMARKIN \\ School of Business, Fairfield University, Fairfield, Connecticut 06430-7524 \\ School of Business, Fairfield University, Fairfield, Connecticut 06430-7524 \\ School of Management, Clark University, Worcester, Massachusetts 01610
}

\begin{abstract}
Our purpose is to examine a firm's optimal output decision and valuation when its shareholders hold a limited number of risky assets. The primary theoretical result indicates that the marketto-book ratio is a function of the degree of shareholder diversification. Our theory suggests a negative relationship between a firm's market-to-book ratio and shareholder diversification.

(MARKET-TO-BOOK RATIO; ANTIDIVERSIFICATION; MAYSHAR CAPM)
\end{abstract}

\section{Introduction}

The relationship between valuation and microeconomic structure under conditions of uncertainty is a contemporary concern. Many articles have appeared recently that link valuation, in the context of the standard capital asset pricing model of Sharpe (1964), Lintner (1965) and Mossin (1966), to a firm's product and factor markets. The most noteworthy to the following analysis are Booth (1981), Conine (1983), Greenberg et al. (1978), Harpaz-Thomadakis (1982), Hite (1977), Lin (1979), Long-Racette (1974), Subrahmanyam-Thomadakis (1980) and Thomadakis (1976).

The purpose of this article is to examine a firm's output decision and market value to book value ratio when its shareholders hold a limited number of risky assets; that is, they hold a subset of the market portfolio. This relationship in this framework has not been examined previously, and it integrates financial valuation with the microeconomic structure of a firm's optimal output decision in a partial equilibrium. ${ }^{1}$ The impact of this limited diversification is examined in the framework of the capital asset pricing model, hereafter CAPM, as formulated by Mayshar (1979), (1981). The microeconomic analogue of the Modigliani-Miller (1961) true growth model, resulting from market imperfections, is developed in a world of limited shareholder diversification.

The primary theoretical result indicates that the market to book ratio is a function of the degree of shareholder diversification, hereafter antidiversification. An intriguing implication of our model is a rationale for converting a public firm to a private firm, i.e. "taking a company private." As in many areas of finance, such as dividend policy, management should be aware of its shareholder clientele. For example, in our model a few undiversified investors, ceteris paribus, would place a higher value on the firm than would many diversified investors. A suggestion is presented as to how management can determine easily the degree to which its shareholders are diversified. There are three pragmatic (and related) reasons for examining how antidiversification affects a firm's valuation. First, the observed behavior of individual investors demonstrates that the majority hold imperfectly diversified portfolios. ${ }^{2}$ The second reason is that, since the

\footnotetext{
* Accepted by William T. Ziemba; received August 1985. This paper has been with the authors 13 months for 3 revisions.

${ }^{1}$ For a concise survey of the financial determinants of systematic risk, see Bowman (1979). SubrahmanyamThomadakis (1980) derived the relationship between systematic risk and microeconomic variables such as Lerner's index of monopoly power (which is directly related to the reciprocal of the price elasticity of demand), and the labor-capital ratio of a firm.

${ }^{2}$ In the Wharton Survey of 1975 (Blume and Friend 1978), the median number of stocks held was found to be fewer than four, with 34 percent holding no more than two. Blume and Friend (1975) found that based
} 
inception of testing the standard CAPM, researchers have often found that variance (in addition to beta) is a significant explanatory variable of returns. ${ }^{3}$ While all empirical tests do not agree, the evidence suggests that variance not be overlooked. Third, surveys have shown that the standard CAPM has gained a widespread acceptance for cost of capital estimation for both regulated and nonregulated firms. Considering the evidence of average investor stock holdings, results of empirical testing of the CAPM, and widespread acceptance of the standard CAPM for cost of equity capital estimation, the question of an optimal output decision in a world of antidiversification is of more significance than simply theoretical argument.

$\$ 2$ provides a review of the Mayshar CAPM. In $\S 3$ the theoretical relationship between valuation and antidiversification is developed. In $\$ 4$ we empirically examine the relationship between market-to-book ratios and shareholder diversification. The final section concludes the analysis.

\section{Asset Pricing with Antidiversification}

The absence of transaction costs in the standard capital asset pricing model is often viewed as being a minor idealization. As Mayshar (1979), (1981) has shown, however, even with relatively small fixed transaction costs the risk premium of an asset will depend upon a weighted average of its covariance with the market and its own-variance. ${ }^{4}$ This result obtains because with transaction costs it is apparent that an investor may not trade in all risk assets. As a result, variance although diversifiable, can be relevant to the pricing of a risk asset. In the standard CAPM with no market frictions, all investors own the market portfolio and therefore are totally diversified. Variance plays no direct role in the valuation of a risk asset. Transaction costs in the Mayshar CAPM include not only brokers' fees and losses due to the bid-ask spread but also include various other obstacles to trade, such as nondivisibility of assets, shortsale restrictions, institutional restraints, and even the subjective costs of managing one's own portfolio. For a further discussion of the nature of transaction costs see Mayshar (1978).

The weights, applied to both an assets covariance with the market and its own variance, are a function of the degree of diversification of the firm's shareholders. The implication

on a sample of individual income tax returns from 1971 considering only dividend paying stocks, 35.15 percent of investors held only one stock, 50.51 percent of investors held no more than two, and 10.72 percent held ten or more stocks. Blume, Friend and Crockett (1974) in a study that included nondividend paying stocks found the median number of holdings of stock was two, while the average was 3.41. In both Blume and Friend (1975) and (1978) other measures of diversification were employed with the results confirming the conclusion that individual investors are, on average, highly undiversified.

${ }^{3}$ In an early test, Douglas (1968) found residual variance to be a significant explanatory variable. MillerScholes (1972) also found residual variance to be a significant explanatory variable and concluded that skewness in the return generating process caused the observed association. In contrast, Fama and MacBeth (1973), using portfolio grouping procedures, found that coefficient of residual variance was not significantly different from zero. Roll (1977) argued that the grouping procedures reduced the skewness in return distributions and accounted for the difference between Fama and MacBeth (1973) and Miller-Scholes (1972). However, Friend, Westerfield and Granito (1978) discovered that with broader market indexes residual standard deviation was extremely significant in both individual asset and grouping tests, thus suggesting that return skewness may not be an adequate explanation. Levy (1979), in an analysis similar to Mayshar (1981), also found that variance was a very significant explanatory variable (even more so than beta). We recognize that even though tests use residual variance and variance, in theory they are not the same. That is, residual variance is that part of variance that is diversifiable. Lakonishok-Shapiro (1986) also examines the impact of variance in the return generating process.

We acknowledge Roll's (1977) criticism which suggests that a valid test of the CAPM has not been made, and it is doubtful that a valid test can be made.

${ }^{4}$ A similar result has been shown by Levy (1979), and has been argued by Lintner (1978) and Tobin and Brainard (1977). 
is that own-variance can affect significantly both the equilibrium rate of return and market valuation of an asset.

The market value, $S_{j}$, formulation of the Mayshar (1981) CAPM is given by ${ }^{5}$

$$
S_{j}=\frac{1}{1+R}\left\{E\left(\mathrm{CF}_{j}\right)-\lambda_{j}\left[d_{j} \operatorname{cov}\left(\mathrm{CF}_{j}, \mathrm{CF}_{m}\right)+\left(1-d_{j}\right) \sigma_{\mathrm{CF}_{j}}^{2}\right]\right\}
$$

where $R$ is the risk free rate, $E\left(\mathrm{CF}_{j}\right)$ is the expected cash flow of a firm $j, \lambda_{j}$ is the market price of risk, $\operatorname{cov}\left(\mathrm{CF}_{j}, \mathrm{CF}_{m}\right)$ is the covariance between the cash flow of firm $j$ and market portfolio, $\sigma_{\mathrm{CF}_{j}}^{2}$ is the variance of the cash flow of firm $j$, and $d_{j}$ which is constrained to be bounded by zero and one represents the degree to which the shareholders of firm $j$ are diversified. If $d_{j}$ equals one, all shareholders own the market portfolio and equation (1) reduces to the standard CAPM. As the degree of antidiversification increases, $d_{j}$ approaches zero. When $d_{j}$ equals zero, asset $j$ is the only risky asset held by each of the investors in $j$. Under this extreme form of antidiversification only own-variance matters. There is no reason for the market value of $j$ to depend upon its covariance with other assets.

A fundamental question in the implementation of the Mayshar CAPM is the estimation of the firm's $d_{j}$. One can argue it is incumbent upon management to know who its shareholders are. This may not be feasible in very large publicly traded firms (except that management certainly has access to shareholder lists routinely compiled by the firm's Transfer Agent). A reasonable (downside) proxy can be the percentage of shares outstanding held by institutional investors (we assume that the vast majority of institutional investors, because of fiduciary responsibility, employ fairly diversified investment strategies). ${ }^{6}$ In Table 1 can be found data available from quarterly reports filed by institutions with the SEC (this covers investment advisers, banks, insurance companies and mutual funds). It is evident that substantial variation exists in the institutional ownership of common stock, even within an industry. Surveys also have shown that these types of companies use the standard CAPM in the estimation of their cost of equity capital. The average institutional ownership of all publicly traded companies in the U.S., at monthend June 1986, was 35.9 percent. While institutional investment concentration certainly changes over time, this evidence, linked with the aforementioned survey evidence of average individual investor stock holdings, results of empirical testing of the CAPM, and recognition that the standard CAPM has received widespread acceptance for cost of capital estimation, suggest that management should be aware of its shareholder clientele for its impact on decision-making.

\section{The Model}

In this section we derive a firm's market value to book value ratio in a world of antidiversification. The development is similar to Thomadakis (1976), SubrahmanyamThomadakis (1980), and Conine (1983). An all-equity firm in a taxless world is assumed.

We first rewrite equation (1) as

$$
S_{j}(1+R)=E\left(\mathrm{CF}_{j}\right)-\lambda_{j}\left\{d_{j} \sigma_{\mathrm{CF}_{j}}^{2}+d_{j} \operatorname{cov}^{*}\left(\mathrm{CF}_{j}, \mathrm{CF}_{m}\right)+\left(1-d_{j}\right) \sigma_{\mathrm{CF}_{j}}^{2}\right\}
$$

where $\operatorname{cov} *\left(\mathrm{CF}_{j}, \mathrm{CF}_{m}\right)=\operatorname{cov}\left(\mathrm{CF}_{j}, \mathrm{CF}_{m}-\mathrm{CF}_{j}\right)$.

\footnotetext{
${ }^{5}$ Our equation (1) is Mayshar's equation (17), the basic result of his paper. Mayshar's equation (17) is in a unit formulation; therefore, as he suggests (1981, p. 589), multiply both sides of his equation (17) by the number of units of the asset to arrive at the aggregate market value given by our equation (1). As discussed by Mayshar (1979), (1981) the assignment problem of which assets are held by a particular investor is exogenous, only the equilibrium values and rates of return are derived. In addition, see Mayshar (1978).

${ }^{6}$ As pointed out by an anonymous referee, the number of investors in an asset may not be synonymous with the degree of diversification of those investors.
} 
TABLE 1

Institutional Ownership of Common Stock $A$ Proxy for $d_{j}$

\begin{tabular}{lc}
\hline \multicolumn{1}{c}{ Company } & $\begin{array}{c}\text { Percentage of Common Stock } \\
\text { held by Institutions }\end{array}$ \\
\hline International Business Machines & 48.5 \\
General Electric & 48.8 \\
Exxon Corporation & 33.0 \\
General Motors Corporation & 38.6 \\
Philip Morris, Inc. & 60.6 \\
Eastman Kodak Company & 46.1 \\
Minnesota Mining and Manufacturing & 60.9 \\
Atlantic Richfield Company & 50.8 \\
Digital Equipment Corporation & 86.4 \\
Standard Oil Company (Indiana) & 35.3 \\
\hline
\end{tabular}

* The ten largest companies in the U.S. ranked by market value of institutional holdings as of month-end June 1986 as found in Barron's.

Rearranging (2) and using an approximation so that the firm specific $\lambda_{j} d_{j}$ can be replaced by $\lambda$ a market-wide parameter, ${ }^{7,8}$ we obtain

$$
S_{j}(1+R)=E\left(\mathrm{CF}_{j}\right)-\lambda\left[\operatorname{cov} *\left(\mathrm{CF}_{j}, \mathrm{CF}_{m}\right)+f \sigma_{\mathrm{CF} j}^{2}\right]
$$

where $f=1 / d_{j}$.

There are several ways uncertainty can enter the demand-price trade-off. We use the multiplicative demand function of Dhrymes (1964). It is given by (tildes denote random variables )

$$
\tilde{P}_{j}=\tilde{a}_{j} Q_{j}^{(-1 / \eta)} \quad \text { where }
$$

$P_{j}=$ price per unit sold of the $j$ th firm,

$Q_{j}=$ output of $j$ th firm,

$\eta=$ the constant elasticity in absolute value $(\eta>1)$, and 9.10

$a_{j}=$ the random demand parameter assumed to follow a zero drift random walk.

The realization of the demand parameter reflects changes in any of the factors in the determination of the demand-price trade-off. Examples are realizations of aggregate income, consumer preferences, and changes in the prices of substitutes and complements. These factors induce shifts in the demand-price trade-off rather than movement along it.

\footnotetext{
${ }^{7}$ We assume, as in Mayshar (1979), for mathematical tractability, that all investors exhibit identical cautiousness and have homogeneous expectations of cash flows (in Mayshar (1981) heterogeneity among investors with respect to expected cash flow was introduced).

${ }^{8}$ More specifically, the approximation depends upon the assumption that holders of different assets have no systematic differences in their degree of risk aversion. Mayshar (1981) discusses the ramifications of reformulating the model to this additional assumption.

${ }^{9}$ To show that constant elasticity is implied by the multiplicative demand function requires the simultaneous substitution of the first derivative of equation (4) with respect to demand, and equation (4) itself into the formulation for price elasticity of demand. A model with constant elasticity is utilized because (1) the majority of empirical studies have employed logarithmic regression, and (2) elasticity is not constant along linear demandprice relationship.

${ }^{10}$ The constant elasticity in absolute value is assumed to be greater than one to satisfy the second-order condition for maximization. This is consistent with Greenberg et al. (1978), Subrahmanyam-Thomadakis (1980) and Thomadakis (1976).
} 
The total revenue for the $j$ th firm is then expressed as

$$
\tilde{\mathrm{T}} \mathrm{R}_{j}=\tilde{a}_{j} Q_{j}^{[(\eta-1) / \eta]}
$$

where $\mathrm{TR}_{j}$ is the total revenue.

The variable cost per unit sold is denoted by $V_{j}$ and for mathematical tractability is assumed constant. After optimal output is determined, sufficient capital is obtained at a cost of $K$ per unit of output. The per unit liquidation value also is assumed to be $K$. Normatively, this liquidation value will represent a return of initial capital. The random end-of-period cash flow $j$ then is given by

$$
\tilde{\mathrm{C}} \mathrm{F}_{j}=\tilde{a}_{j} Q_{j}^{[(\eta-1) / \eta]}-V_{j} Q_{j}+K Q_{j} .
$$

Since the Mayshar CAPM is cast in a single period, the firm is assumed to invest sufficiently at the beginning of the period to produce the optimal output. At the end of the period the firm adjusts the price to clear the market. All trading is assumed to take place at the end of the period, when realization of total revenue, cost and liquidation value occurs.

The optimal output will be the $Q_{j}$ which maximizes the net present value of the firm, $S_{j}-K Q_{j}$. We now express equation (3) in the context of the micro-economic variables by using equation (6),

$$
\begin{aligned}
S_{j}(1+R)=E\left(a_{j}\right) Q_{j}^{[(\eta-1) / n]}+( & \left.-V_{j}\right) Q_{j} \\
& -\lambda\left[Q_{j}^{(\eta-1) / \eta} \operatorname{cov}^{*}\left(a_{j}, \mathrm{CF}_{m}\right)+f Q_{j}^{[2(\eta-1) / \eta]} \sigma_{a_{j}}^{2}\right] .
\end{aligned}
$$

Before forming the net present value (NPV), we make a notational transformation. Let $\delta=\eta /(\eta-1)$ and $Z=Q^{1 / \delta}$. The NPV now equals $S_{j}-K Z^{\delta}$ so that

$$
\mathrm{NPV}=(1 / 1+R)\left\{Z E\left(a_{j}\right)-\left[V_{j}+K R\right] Z^{\delta}-\lambda\left[Z \operatorname{cov} *\left(a_{j}, \mathrm{CF}_{m}\right)+Z^{2} f \sigma_{a_{j}}^{2}\right]\right\} .
$$

To maximize end of period market value requires determination of the optimal output that maximizes the net present value made at the beginning of the single period. Optimizing (8) with respect to $Z$ we obtain

$$
\begin{gathered}
E\left(a_{j}\right)-\lambda \operatorname{cov}^{*}\left(a_{j}, \mathrm{CF}_{m}\right)-2 \lambda \sigma_{a_{j}}^{2} f Z^{*}-\delta\left[V_{j}+K R\right] Z^{* \delta-1}=0 \quad \text { or } \\
E\left(a_{j}\right)-\lambda \operatorname{cov}^{*}\left(a_{j}, \mathrm{CF}_{m}\right)-2 \lambda \sigma_{a_{j}}^{2} f Z^{*}=\delta\left[V_{j}+K R\right] Z^{* \delta-1}
\end{gathered}
$$

and $Z^{*}$ represents optimal output.

Equation (9) is an implicit function for optimal output that cannot be solved in closed form for an arbitrary price elasticity of demand. Conceptually, the net present value is the present value of market imperfections (or monopoly rents) arising from barriers to entry and is seen to be a function of shareholder diversification. In the Modigliani-Miller world, equation (9) represents the capitalized value of: (1) the differential of realized and required return, (2) the duration of the differential, and (3) the level of investment. This equation is thus a microeconomic equivalent of the Modigliani-Miller true growth model in a world of antidiversification. ${ }^{11}$

A major concern in the field of Industrial Organization is an appropriate proxy for monopoly power. Frequently, seller concentration, size, or profitability is taken to be the measure of monopoly power. See Sullivan (1974), (1977), (1978), (1982) and Weiss (1974) for an elaboration. The more theoretical market value-to-book value ratio is another often examined measure of monopoly power (e.g. see Thomadakis 1977 and Sullivan 1974, 1977, 1978) and may be derived by dividing equation ( 8 ) by the book

\footnotetext{
${ }^{11}$ The usual caveat of integrating a single-period model with a multi-period model applies.
} 
value of assets, $K Q_{j}$ (i.e., by $K Z^{\delta}$ ), after solving for $S_{j}$. The market-to-book ratio, $M B_{j}$, then is given by

$$
M B_{j}^{*}=1+\left[\frac{1}{K(1+R)}\right]\left\{\lambda f \sigma_{a_{j}}^{2} Z^{* 2-\delta}+\left(V_{j}+K R\right)(\delta-1)\right\} .
$$

The relationship between shareholder diversification, $d_{j}$, and the NPV optimizing output, $Z^{*}$, is worthy of examination even though equation (10) is not tractable. A drawing of the left-hand side (LHS) versus the right-hand side (RHS) of (10) for various values of $f$ is presented in Figure 1 and clearly illustrates the relationship. The solution set where the LHS equals the RHS is given by the intersections, marked by circles, a smaller $f$ (i.e., a larger $d_{j}$ ), which signifies more shareholder diversification, increases the optimal output.

The relationship between shareholder diversification and a firm's market-to-book ratio is somewhat clouded given that optimal output is itself a function of $d_{j}$. Given $Z^{*}$, however, a straightforward reading of equation (11) shows that a smaller $f$ (i.e., a larger $d_{j}$ ) which signifies more shareholder diversification, decreases the market-to-book ratio.

An interesting question is what happens to a firm's market-to-book ratio under perfectly competitive pricing (i.e., $\eta$ goes to infinity). In the limit, equation ( 11 ) becomes (restoring $Q^{1 / \delta}$ for $Z$ )

$$
M B_{j}=1+\frac{1}{K(1+R)}\left\{\lambda f \sigma_{a_{j}}^{2} Q_{j}\right\} .
$$

In the context of the standard CAPM, it is a well-known result that competitive pricing implies a market-to-book ratio (Tobin's $Q$ ) of one. Within the Mayshar framework, however, Tobin's $Q$ is greater than one even under perfect competition. This result obtains because the pricing mechanism allows for unsystematic as well as systematic risk. Therefore, the extant literature that finds under perfect competition that Tobin's $Q$ is one implicitly must assume perfect shareholder diversification (a result not consistent with the aforementioned surveys). It should be noted that the determination of all variables is generally simultaneous. ${ }^{12}$ Thus, for example, the reader should be careful in trying to go from equation 12 to the perfect diversification case because a substitution of $d_{j}$ equal to one in equation (1) results in variance not being priced.

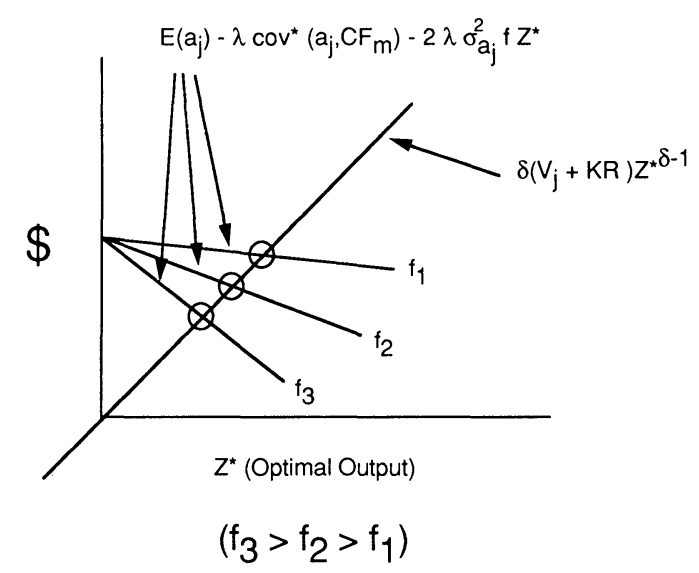

FIGURE 1. The Relationship Between Shareholder Diversification and Optimal Output.

\footnotetext{
${ }^{12}$ We are grateful to an anonymous referee for making this point.
} 
TABLE 2

Regression Summary

\begin{tabular}{|c|c|c|c|c|}
\hline Industry & Firms $(N)$ & $\rho_{d_{j}, M B_{j}}$ & $\alpha_{0}$ & $\alpha_{1}$ \\
\hline Aerospace & 8 & 0.403 & $\begin{array}{c}1.202 \\
(2.088)\end{array}$ & $\begin{array}{c}0.014 \\
(1.078)\end{array}$ \\
\hline Airlines & 6 & -0.826 & $\begin{array}{c}2.103 \\
(6.563)\end{array}$ & $\begin{array}{l}-0.156 \\
(-2.932)^{*}\end{array}$ \\
\hline Appliances & 4 & -0.939 & $\begin{array}{c}7.019 \\
(5.322)\end{array}$ & $\begin{array}{l}-0.823 \\
(-3.860)^{*}\end{array}$ \\
\hline Automotive & 14 & -0.325 & $\begin{array}{c}1.747 \\
(4.156)\end{array}$ & $\begin{array}{c}-0.009 \\
(-1.191)\end{array}$ \\
\hline Banks & 46 & -0.420 & $\begin{array}{c}1.556 \\
(10.022)\end{array}$ & $\begin{array}{l}-0.009 \\
(-3.067)^{*}\end{array}$ \\
\hline Beverages & 8 & 0.461 & $\begin{array}{c}1.479 \\
(1.712)\end{array}$ & $\begin{array}{c}0.026 \\
(1.271)\end{array}$ \\
\hline Building Materials & 10 & -0.047 & $\begin{array}{c}1.518 \\
(1.523)\end{array}$ & $\begin{array}{c}-0.003 \\
(-0.133)\end{array}$ \\
\hline Chemicals & 29 & 0.069 & $\begin{array}{c}1.432 \\
(4.718)\end{array}$ & $\begin{array}{c}0.002 \\
(0.362)\end{array}$ \\
\hline Conglomerates & 18 & -0.525 & $\begin{array}{c}2.400 \\
(6.122)\end{array}$ & $\begin{array}{c}-0.020 \\
(-2.467)^{*}\end{array}$ \\
\hline Containers & 5 & -0.986 & $\begin{array}{c}2.662 \\
(21.895)\end{array}$ & $\begin{array}{c}-0.026 \\
(-10.382)^{*}\end{array}$ \\
\hline Drugs & 18 & 0.081 & $\begin{array}{c}2.624 \\
(2.434)\end{array}$ & $\begin{array}{c}0.006 \\
(0.324)\end{array}$ \\
\hline Electronics & 27 & -0.248 & $\begin{array}{c}2.826 \\
(4.415)\end{array}$ & $\begin{array}{c}-0.016 \\
(-1.281)\end{array}$ \\
\hline Food Processing & 33 & -0.061 & $\begin{array}{c}2.472 \\
(4.199)\end{array}$ & $\begin{array}{c}-0.005 \\
(-0.339)\end{array}$ \\
\hline Food \& Lodging & 12 & -0.291 & $\begin{array}{c}3.354 \\
(3.573)\end{array}$ & $\begin{array}{c}-0.018 \\
(-0.964)\end{array}$ \\
\hline General Machinery & 10 & -0.489 & $\begin{array}{c}1.774 \\
(4.000)\end{array}$ & $\begin{array}{l}-0.012 \\
(-1.589)^{* *}\end{array}$ \\
\hline Instruments & 7 & 0.541 & $\begin{array}{c}0.671 \\
(1.078)\end{array}$ & $\begin{array}{c}0.016 \\
(1.441)\end{array}$ \\
\hline Leisure Time & 15 & -0.310 & $\begin{array}{c}3.301 \\
(3.322)\end{array}$ & $\begin{array}{c}-0.026 \\
(-1.174)\end{array}$ \\
\hline Metals & 5 & -0.406 & $\begin{array}{c}1.605 \\
(1.929)\end{array}$ & $\begin{array}{c}-0.012 \\
(-0.769)\end{array}$ \\
\hline Misc. Manufacturing & 40 & -0.049 & $\begin{array}{c}1.886 \\
(3.891)\end{array}$ & $\begin{array}{c}-0.003 \\
(-0.299)\end{array}$ \\
\hline Natural Resources & 28 & 0.262 & $\begin{array}{c}1.037 \\
(3.986)\end{array}$ & $\begin{array}{l}0.008 \\
(1.386)^{* *}\end{array}$ \\
\hline
\end{tabular}


TABLE 2 (cont'd)

\begin{tabular}{|c|c|c|c|c|}
\hline Industry & Firms $(N)$ & $\rho_{d_{j}, M B_{j}}$ & $\alpha_{0}$ & $\alpha_{1}$ \\
\hline Nonbank Financial & 34 & -0.238 & $\begin{array}{c}2.855 \\
(3.931)\end{array}$ & $\begin{array}{c}-0.019 \\
(-1.384)^{* *}\end{array}$ \\
\hline Office Equipment & 16 & -0.122 & $\begin{array}{c}2.230 \\
(2.441)\end{array}$ & $\begin{array}{c}-0.007 \\
(-0.461)\end{array}$ \\
\hline Oil Service & 15 & 0.138 & $\begin{array}{c}0.848 \\
(2.756)\end{array}$ & $\begin{array}{c}0.003 \\
(0.505)\end{array}$ \\
\hline Paper & 24 & -0.319 & $\begin{array}{c}1.948 \\
(5.757)\end{array}$ & $\begin{array}{c}-0.012 \\
(-1.579)^{* *}\end{array}$ \\
\hline Personal Care & 7 & -0.603 & $\begin{array}{c}4.076 \\
(4.613)\end{array}$ & $\begin{array}{c}-0.031 \\
(-1.689)^{* *}\end{array}$ \\
\hline Publishing & 18 & -0.177 & $\begin{array}{c}4.357 \\
(4.334)\end{array}$ & $\begin{array}{c}-0.015 \\
(-0.718)\end{array}$ \\
\hline Railroads & 6 & 0.116 & $\begin{array}{c}0.992 \\
(2.012)\end{array}$ & $\begin{array}{c}0.002 \\
(0.234)\end{array}$ \\
\hline Real Estate & 4 & -0.056 & $\begin{array}{c}1.570 \\
(1.181)\end{array}$ & $\begin{array}{c}-0.002 \\
(-0.080)\end{array}$ \\
\hline Retailing (Food) & 17 & -0.423 & $\begin{array}{c}3.402 \\
(6.173)\end{array}$ & $\begin{array}{c}-0.024 \\
(-1.810)^{*}\end{array}$ \\
\hline Retailing (Non-Food) & 46 & -0.253 & $\begin{array}{c}3.409 \\
(5.321)\end{array}$ & $\begin{array}{c}-0.023 \\
(-1.738)^{*}\end{array}$ \\
\hline Service & 63 & -0.181 & $\begin{array}{c}3.272 \\
(5.006)\end{array}$ & $\begin{array}{c}-0.019 \\
(-1.439)^{* *}\end{array}$ \\
\hline Special Machinery & 10 & -0.290 & $\begin{array}{c}1.933 \\
(2.583)\end{array}$ & $\begin{array}{c}-0.012 \\
(-0.858)\end{array}$ \\
\hline Steel & 8 & -0.586 & $\begin{array}{c}2.360 \\
(3.267)\end{array}$ & $\begin{array}{c}-0.030 \\
(-1.770)^{* *}\end{array}$ \\
\hline Textiles & 16 & -0.002 & $\begin{array}{c}1.410 \\
(2.558)\end{array}$ & $\begin{array}{c}-0.001 \\
(-0.009)\end{array}$ \\
\hline Tires & 6 & -0.810 & $\begin{array}{c}2.104 \\
(5.265)\end{array}$ & $\begin{array}{c}-0.021 \\
(-2.762)^{*}\end{array}$ \\
\hline Tobacco & 4 & 0.259 & $\begin{array}{c}1.462 \\
(0.893)\end{array}$ & $\begin{array}{c}0.014 \\
(0.379)\end{array}$ \\
\hline Trucking & 7 & -0.244 & $\begin{array}{c}2.558 \\
(2.667)\end{array}$ & $\begin{array}{c}-0.009 \\
(-0.563)\end{array}$ \\
\hline
\end{tabular}

* Significant at $5 \%$ level (t-statistics in parentheses)

** Significant at $10 \%$ level (t-statistics in parentheses)

\section{Empirical Analysis}

In this section we empirically examine the result that a firm's market-to-book ratio is negatively related to shareholder diversification.

Our proxy for shareholder diversification, $d_{j}$, is the aforementioned percentage of shares 
held by institutional investors, a measure also used by Lakonishok and Shapiro (1986) in the same context. To hold constant the micro-effects, we examined 37 industries using 1985 year-end data from Forbes January 13, 1986 for the following regression (regulated industries were eliminated because market-to-book ratios are constrained close to one $)^{13}$

$$
M B_{j}=\alpha_{0}+\alpha_{1} d_{j}+\epsilon_{j} \quad \text { where }
$$

$M B_{j}=$ the market price-to-book ratio,

$d_{j}=$ proportion of outstanding shares held by institutional investors,

$\alpha_{0}, \alpha_{1}=$ intercept and slope estimates, respectively, and

$\epsilon_{j}=$ error term.

The results are presented in Table 2 . Of the 37 industries, 14 have statistically significant negative coefficients ( 8 at 5\% and 6 at 10\%) with only one significant coefficient being positive (at $10 \%$ ). Thus, 14 of the 37 industries are consistent with the theoretical result which predicts a negative relationship between price-to-book ratio and shareholder diversification. The statistically nonsignificant results (of the remaining 22 industries 14 did have a negative sign ) may, of course, result from many factors, such as, homogeneity within industry groups and small sample sizes. Future research might look at time series as well as other cross-sectional models.

\section{Conclusion}

The linkage between financial valuation and the product and factor markets faced by the firm is an area rapidly developing in the literature. Our purpose is to examine a firm's optimal output decision and valuation when its shareholders hold a limited number of risky assets. The primary theoretical result indicates that the market-to-book ratio is a function of the degree of shareholder diversification. Our theory suggests a negative relationship between a firm's market-to-book ratio and shareholder diversification. We suggest how management can ascertain the degree of its shareholders' diversification. Finally, our empirical results, while not conclusive, should inspire future research.

\footnotetext{
${ }^{13}$ We recognize that numerous studies have related market price-to-book value ratios to a wide variety of independent variables. We have avoided adding variables that may not have strong theoretical justification.
}

\section{References}

Blume, M. AND I. FRIEND, “The Asset Structure of Individual Portfolios and Some Implications for Utility Functions," J. Finance, (May 1975).

- AND The Changing Roles of the Individual Investor: A Twentieth-Century Fund Report, John Wiley and Sons, New York, 1978.

- - AND J. CROCKETT, "Stock Ownership in the United States: Characteristics and Trends," Survey of Current Business, (November 1974).

Воотн, L., "Stochastic Demand, Output and the Cost of Equity Capital," J. Finance, (June 1980).

- "Market Structure Uncertainty and the Cost of Equity Capital," J. Banking and Finance, (1981).

BOWMAN, R., "The Theoretical Relationship between Systematic Risk and Financial (Accounting) Variables," $J$. Finance, (June 1979).

CONINE, T., "On the Theoretical Relationship between Systematic Risk and Price Elasticity of Demand," $J$. Business Finance and Accounting, (Summer 1983).

DHRYMES, P., "On the Theory of the Monopolistic Multiproduct Firm Under Uncertainty," Internat. Economic Rev., (September 1964).

Douglas, G., Risk in the Equity Markets: An Empirical Appraisal of Market Efficiency, University Microfilms, Inc., Ann Arbor, MI, 1968.

Fama, E. AND J. MaCBeth, "Risk, Return and Equilibrium: Empirical Tests,” J. Political Economy, (May 1973).

Friend, I., R. Westerfield and M. Granito, "New Evidence on the Capital Asset Pricing Model," $J$. Finance, (June 1978).

Greenberg, E., W. Marshall and J. Yawitz," The Technology of Risk and Return," Amer. Economic Rev., (June 1978). 
1981)

Harpaz, G. AND S. Thomadakis, “Systematic Risk and the Firm's Experimental Strategy,” J. Financial and Quantitative Anal., (September 1982).

Hite, G., "Leverage, Output Effects and the M-M Theories," J. Financial Economics, (March 1977).

JAMES, C., "The Technology of Risk and Return: Comment," Amer. Economic Rev., (June 1981).

LAKONISHOK, J. AND A. SHAPIRO, "Systematic Risk, Total Risk and Size as Determinants of Stock Market Returns," J. Banking and Finance, 10 (1986).

LEVY, H., "Equilibrium in an Imperfect Market. A Constraint on the Number of Securities in the Portfolio," Amer. Economic Rev., (September 1979).

LIN, W., "Capital and Labor Market Equilibrium with Stochastically Varying Price Level and Wages," $J$. Economics and Business, (Fall 1979).

LINTNER, J., "The Valuation of Risk Assets and the Selection of Risky Investments in Stock Portfolios and Capital Budgets," Rev. Economics and Statist., (February 1965).

_, "The Aggregation of Investors' Diverse Judgements and Preferences in Purely Competitive Security Markets," J. Financial and Quantitative Anal., (December 1978).

LONG, M. AND G. RACETTE, "Stochastic Demand, Output and the Cost of Capital," J. Finance, (May 1974).

MAYSHAR, J., "Investors' Time Horizon and the Inefficiency of Capital Markets," Quart. J. Economics, (May 1978).

—_, "Transaction Costs in a Model of Capital Market Equilibrium," J. Political Economy, (August 1979).

- "Transaction Costs and the Pricing of Assets," J. Finance, (June 1981).

Miller, M. AND M. Scholes, "Rates of Return in Relation to Risks: A Re-examination of Some Recent Findings," M. C. Jensen (Ed.), Studies in the Theory of Capital Markets, Praeger, New York, 1972.

Modigliani, F. AND M. Miller, “Dividend Policy, Growth and the Valuation of Shares," J. Business, (October $1961)$.

Mossin, J., "Equilibrium in a Capital Asset Market," Econometrics, (October 1966).

Roll, R., “A Critique of the Asset Pricing Theory's Tests," J. Financial Economics, (March 1977).

SharPE, W., "Capital Asset Prices: A Theory of Market Equilibrium Under Conditions of Risk," J. Finance, (September 1964).

SubrahmANYAM, M. AND S. ThOMADAKIS, "Systematic Risk and the Theory of the Firm," Quart. J. Economics, (May 1980).

Sullivan, T., "Market Power, Profitability and Financial Leverage," J. Finance, (December 1974).

—, "A Note on Market Power and Return to Stockholders," Rev. Economics and Statist., (February 1977).

—_ "The Cost of Capital and the Market Power of Firms," Rev. Economics and Statist., (May 1978).

—, "The Cost of Capital and Market Power of Firms: Reply and Correction," Rev. Economics and Statist ., (August 1982).

Thomadakis, S., “A Model of Market Power, Valuation and the Firm's Return," Bell J. Economics and Management Sci., (Spring 1976).

, “A Value-Based Test of Profitability and Market Structure," Rev. Economics and Statist., (May 1977).

Tobin, J. AND W. R. Brainard, “Asset Markets and the Cost of Capital," Economic Progress, Private Values, and Public Policy: Essays in Honor of William Fellner, B. Balassa, R. Neison, (Eds.). North Holland, Amsterdam and New York, 1977.

WEISS, L., "The Concentration-Profits Relationship and Anti-trust," H. J. Goldschmid, et al., Industrial Concentration: The New Learning, Little Brown and Co., New York, 1974. 